\section{ISOLATE}

An isolate of HIV-1 is a population of virus that has been recovered from a patient. Isolates that have been distributed to other laboratorie are sometimes called strains.

SUBTYPES OF HIV-1

These are genetically related clusters of HIV-1. Subtypes of HIV-1 are also called clades. They do not fall into specific categories based on their susceptibility to neutralizing antibody.
Vaccine Research Center and Yerkes Primate Research Center of Emory University, 954 Gatewood Drive, NE, Atlanta, Georgia 30329, USA. e-mail: hrobins@rmy.emory.edu DOI: $10.1038 /$ nri776

\title{
NEW HOPE FOR AN AIDS VACCINE
}

\author{
Harriet L. Robinson \\ The twenty-first century has begun with considerable success for new AIDS vaccines in \\ macaque models. A common feature of these vaccines is their ability to induce high-frequency \\ CD8 ${ }^{+}$T-cell responses that control, rather than prevent, infection with HIV. The new vaccines, \\ which include DNA vaccines and live viral vectors, are based on technologies that have been \\ developed since the start of the AIDS epidemic. The ultimate promise of these vaccines will be \\ realized only when efficacy trials in humans are conducted.
}

\section{VACCINES (0)}

Although HIV type 1 (HIV-1) was successfully grown in tissue culture ${ }^{1,2}$ and completely sequenced ${ }^{3}$ within four years of the first reports of AIDS in 1981 (REF. 4), it is only recently that vaccine strategies against this scourge of the twenty-first century have shown promise in terms of both safety and efficacy. HIV-1 has presented several unique challenges for vaccine development (BOX 1). Viral envelope (Env) glycoproteins, which mediate attachment and entry into host cells, conceal their conserved receptor- and co-receptor-binding sites in thermostable crypts that are masked further by loops of heavily glycosylated variable sequences ${ }^{5,6}$ (FIG. 1). Antibody-producing B cells recognize the variable loops, but only infrequently recognize the conserved receptor-binding sites ${ }^{7}$, which makes it hard to generate neutralizing antibodies with broad cross-reactivity for patient ISOLATES. HIV-1 has eluded control by vaccines through its ability to form latent proviral DNA. As an essential step in its life cycle, HIV-1 integrates into the genome of its host to form a provirus. Once integrated, the virus can hide from the immune system by its lack of protein expression ${ }^{8}$. Estimates of the half-life of latent proviral DNA range from 6 to 43 months, indicating that it could take up to 60 years to eradicate a reservoir of as few as $1 \times 10^{5}$ latently infected cells ${ }^{9,10}$. Finally, HIV-1 is highly variable ${ }^{11,12}$ : HIV-1 arose from a single transmission event from chimpanzees to humans ${ }^{13}$, but has evolved in humans to form at least 12 genetic SUBTYPES, which, in turn, have diversified further (FIG. 2). Even within a subtype, antibodies that are specific for the variable loops of isolates from one patient typically do not recognize the variable loops of isolates from other patients. As the epidemic has spread, recombinants of different subtypes have gained prominence ${ }^{14}$. The high error rate of reverse transcription generates at least one mutation per provirus ${ }^{15}$, which, combined with the rapid turnover of plasma virions ${ }^{16}$, provides a broad base of variants for selection and escape from both cellular and humoural immune responses ${ }^{7,17}$.

\section{Rationale for vaccine design}

Because of the problems that are associated with raising neutralizing antibodies, recent vaccine approaches have focused on inducing cellular immune responses ${ }^{18,19}$. Cellular immune responses are mediated by white blood cells called $\mathrm{T}$ cells that recognize and respond to foreign peptides (epitopes) that are presented by MHC antigens.

\section{Box 1 Challenges for an AIDS vaccine}

HIV is a difficult target for neutralizing antibodies:

- conserved targets are thermostably concealed

- exposed targets are highly variable

- targets are camouflaged by heavy glycosylation

HIV is able to form latent proviral DNA:

- occurs early in infection

- long half-life

HIV has high variability:

- 12 known subtypes

- intersubtype recombinants

- high error rate of reverse transcriptase 
a

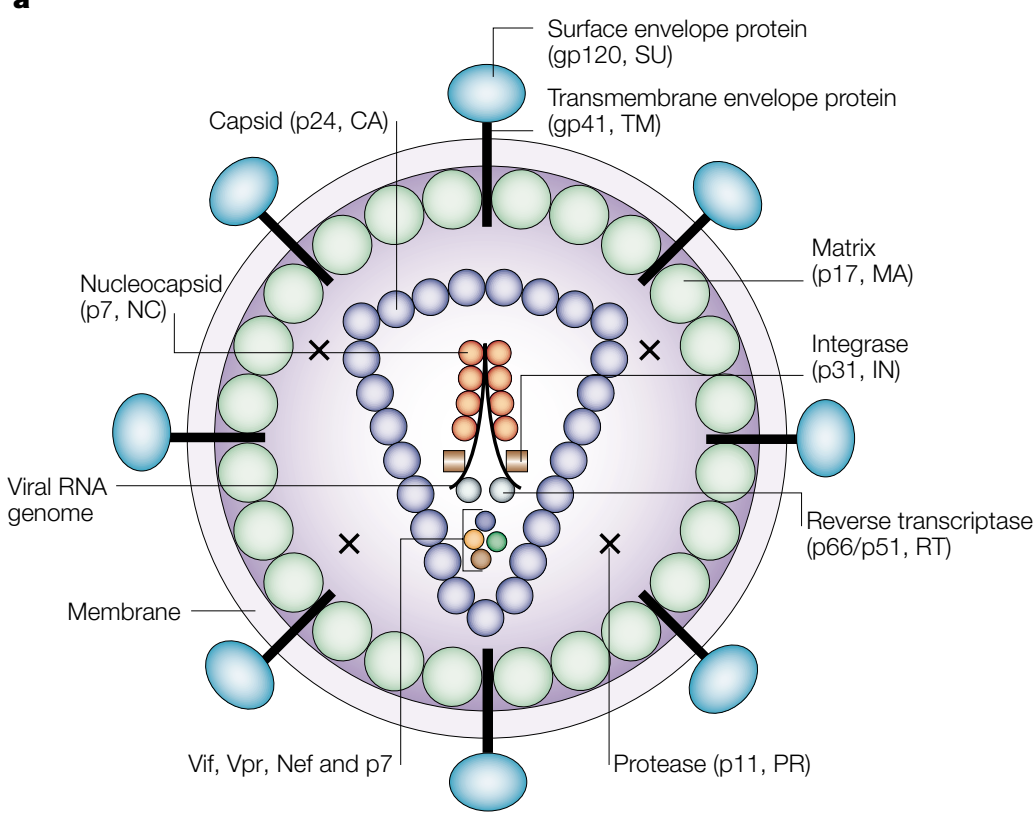

b

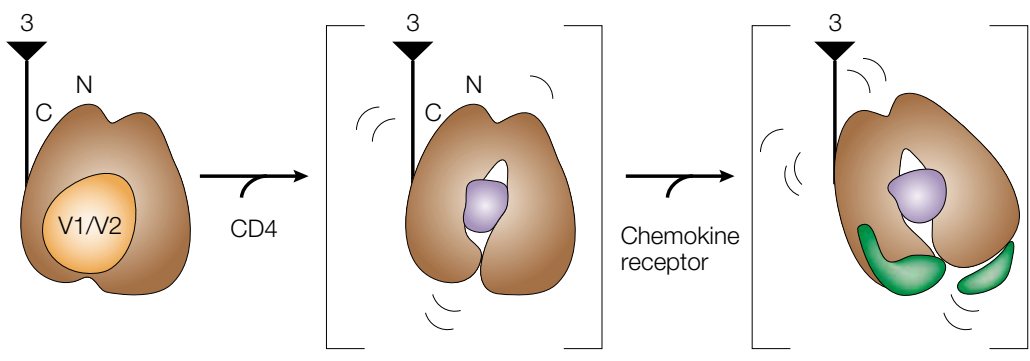

Figure 1 | Structure of HIV-1. a | Schematic of HIV-1 showing the envelope glycoproteins that are targets for neutralizing antibodies and the structural, as well as enzymatic, proteins that are targets for $T$ cells. The longest three reading frames of the virus transcribe the Gag, Env and Pol polyproteins. The Gag polyprotein is processed into MA, CA, NC and p7, which make up the inner core of the viral particle. Glycoprotein 120 (gp120; SU) and gp41 (TM) are derived from the envelope (Env) polyprotein and are the outer membrane proteins of the virus. Processing of the polymerase (Pol) polyprotein yields the enzymes protease (PR), reverse transcriptase (RT) and integrase $(\mathrm{IN})$, which are encapsulated in the core of the inner particle. The accessory proteins Vif, Vpr and Nef are encoded by three other reading frames in the virus. The surface envelope glycoprotein is glycosylated at 25-30 sites, and contains three variable loops that mask receptorbinding sites. Adapted, with permission, from REF. 115. (C) (1998) Academic Press. b | Schematic depicting conformational changes of the gp120 subunit of Env that expose the conserved CD4and co-receptor-binding sites. The ' 3 ' symbolizes the 3 -fold axis, from which gp41 interacts with gp120 to generate a functional trimer. The left-hand schematic depicts the form of gp120 on the surface of a virion. The CD4-binding site is partially occluded by variable loops 1 and 2 (V1N2) shown in orange. The middle form represents a conformational change that is depicted as an inner-outer domain shift, with the purple shape denoting the formation of the CD4-binding cavity. The right-hand schematic depicts a third conformational form, in which the gp120 'bridging sheet' and sequences in the third variable loop (shown in green) bind to the chemokine coreceptor. Adapted, with permission, from Nature (REF. 5) (C) (1998) Macmillan Magazines.

DNA VACCINE

A DNA plasmid that expresses the immunizing protein.

Vaccination is accomplished by uptake and expression of the DNA by cells in the vaccinated host.
$\mathrm{CD}^{+} \mathrm{T}$ cells recognize peptides of $8-11$ amino acids presented by class I MHC, whereas $\mathrm{CD} 4^{+} \mathrm{T}$ cells recognize sequences of 10-14 amino acids presented by class II MHC. These peptides originate from conserved, as well as variable, regions of HIV proteins (FIG. 1a). About $60 \%$ of the $\sim 200 \mathrm{CD} 8^{+} \mathrm{T}$-cell epitopes that have been defined for subtype B of HIV-1 are conserved within subtype B, whereas only about $30 \%$ of these epitopes are conserved in more distantly related subtypes, such as A or $\mathrm{C}^{12,20}$. So, T-cell responses have good cross-reactivity within a subtype and some cross-reactivity across subtypes. Because T-cell responses are restricted to peptides that are presented on MHC, each vaccinated individual recognizes only those peptides that are presented by his or her MHC (about $5 \%$ of the defined epitopes).

$\mathrm{CD}^{+} \mathrm{T}$ cells (cytolytic T cells) directly combat infections, whereas $\mathrm{CD}^{+} \mathrm{T}$ cells (helper $\mathrm{T}$ cells) provide growth factors and co-stimulatory molecules that support the activation and maintenance of $\mathrm{CD} 8^{+} \mathrm{T}$ cells . $\mathrm{CD}^{+} \mathrm{T}$ cells clear infections by lysing infected cells ${ }^{18}$. They also act by suppressing proviral expression through the release of antiviral cytokines, such as tumournecrosis factor (TNF) and interferon- $\gamma(\text { IFN- } \gamma)^{21-23}$. Both $\mathrm{CD}^{+}$and $\mathrm{CD} 4^{+} \mathrm{T}$ cells can block the local spread of HIV by producing chemokines that interfere with the activity of co-receptors for viral entry $y^{22,24,25}$. HIV can escape T-cell responses by mutating sequences within its target epitopes ${ }^{26,27}$. Studies in macaques show a direct correlation between the number of days to death and the number of $\mathrm{CD} 8^{+} \mathrm{T}$-cell epitopes that are recognized by an individual macaque ${ }^{17}$. So, as with antiretroviral drugs, for which multi-drug therapy is more effective than single-drug therapy, to be effective, $\mathrm{T}$-cell responses need to be directed against several HIV-1 sequences. The importance of $\mathrm{CD}^{+} \mathrm{T}$ cells for the control of viral infections has been best shown in macaques, in which the depletion of $\mathrm{CD}^{+} \mathrm{T}$ cells results in the emergence of high levels of viraemia ${ }^{28,29}$. The importance of $\mathrm{CD}^{+}$ T cells is shown by the natural history of AIDS, in which patients progress to disease when they have lost $>80 \%$ of their $\mathrm{CD} 4^{+} \mathrm{T}$ cells.

Proteins that are produced inside cells are the best substrates for raising $\mathrm{CD}^{+} \mathrm{T}$ cells, because these proteins have access to pathways for processing and presentation by class I MHC. In the past, the vaccines that have successfully raised specific $T$ cells have been of the liveattenuated type. However, for immunodeficiency viruses, live-attenuated vaccines have been problematic. Vaccines with sufficient replication capacity to effectively immunize can be virulent in newborn $\mathrm{s}^{30}$ and, occasionally, revert to virulence in adults ${ }^{31}$. So, vaccines that consist of only a portion of a pathogen or a replication-defective mimic of the pathogen are the current preferred candidates for AIDS vaccines. For these to effectively raise $\mathrm{CD} 8^{+} \mathrm{T}$ cells, they need to be expressed in cells. This has been achieved using DNA VACCINES and live viral vectors.

\section{Promising vaccine strategies}

All of the vaccines that have achieved recent success have been designed to induce cell-mediated immunity. These vaccines include interleukin-2 (IL-2)-ADJUVANTED DNA vaccines ${ }^{32}$; regimens consisting of DNA priming followed by recombinant modified vaccinia Ankara (rMVA) ${ }^{33}$ or recombinant human adenovirus 5 (Ad5) boosters $^{34}$ (DNA-rMVA or DNA-Ad5 vaccines); and vaccines that use $\mathrm{rMVA}^{35}$ (R. R. Amara et al., unpublished observations) or Ad5 (REF. 34) for both priming and boosting immunizations (rMVA-only or Ad5-only 


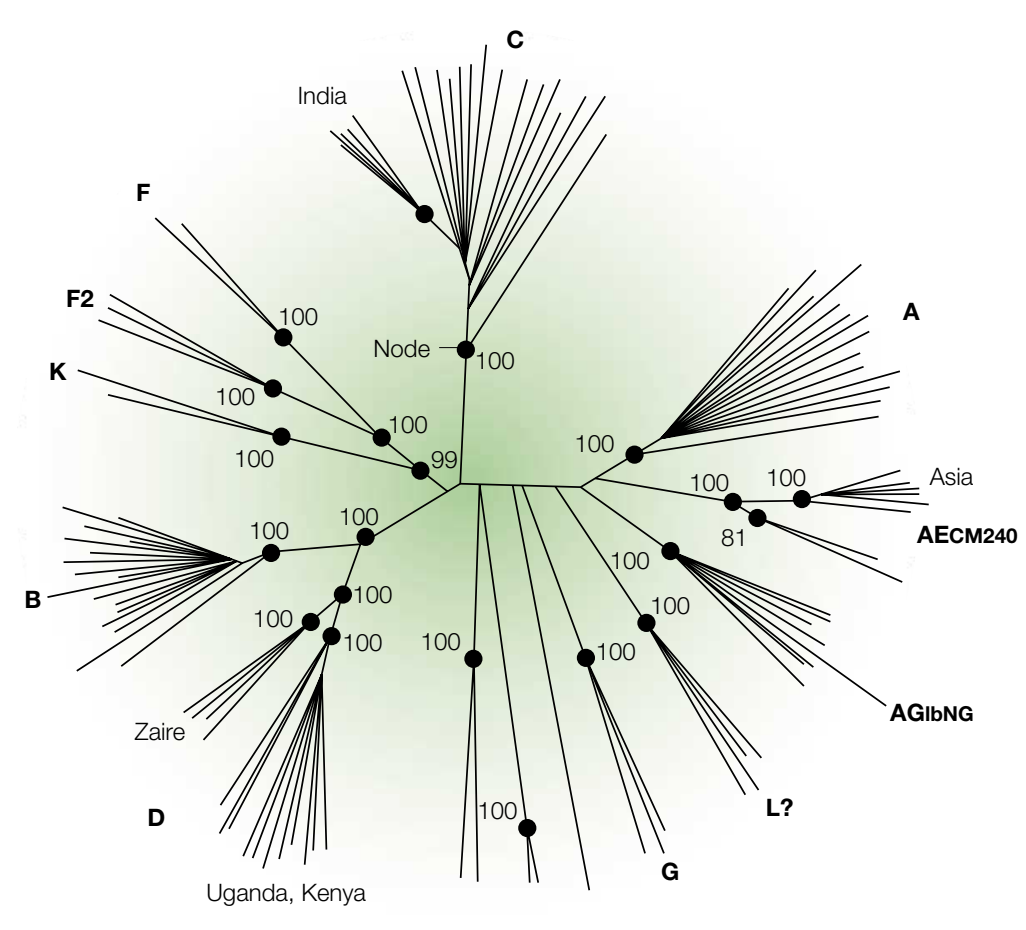

Figure 2 | Genetic relationships of HIV-1 subtypes and circulating recombinant forms. The schematic, which is based on full genome sequences, indicates the relationship of current subtypes of HIV-1 - indicated by the letters A, B, C and so on - and their dominant geographical distributions. The original transmission of HIV-1 from chimpanzee to human is thougth to have occurred at the starting junction for the clusters ${ }^{13}$. The clustal relationship was developed using a statistical method known as bootstrapping, with 100 iterations and 50\% resampling of the datasets (bootstrap values are indicated at the nodes). Data are adapted, with permission, from REF. 116 (C) (2000) Arnold Publishers.

ADJUVANT

Adjuvants are substances that, when added to an immunogen, increase the immune response to that immunogen. Genetic adjuvants are DNAs that encode a molecule that augments an immune response.

LONG-TERM NON-PROGRESSORS HIV-1-infected humans who enjoy many years of productive life. Long-term non-progressors typically have levels of viral RNA in their blood of less than 1000 copies per ml.

CODON OPTIMIZATION Changing the codons for an amino acid to those most frequently used in human cells.

MICROSPHERE

A carrier for a vaccine that facilitates immune responses by stabilizing and/or increasing the uptake of the vaccine. vaccines) (TABLE 1). All of these vaccines have been tested in a single preclinical model: immunogens have been constructed from the 89.6 or $89.6 \mathrm{P}$ hybrids of simian and human immunodeficiency viruses (SHIV), and the highly pathogenic SHIV-89.6P was used for the challenge ${ }^{36}$. SHIV-89.6P establishes steady-state levels of viraemia that are 10-100-times greater than those of HIV-1 in typical infected humans, depletes $\mathrm{CD} 4^{+} \mathrm{T}$ cells within 2-3 weeks of infection ${ }^{32-34,37}$ and causes AIDS in most infected animals within six months. In this model, 7 out of 8 animals immunized with a DNA vaccine that used IL-2 as an adjuvant ${ }^{32,38} ; 23$ out of 24 animals given a DNA-rMVA vaccine ${ }^{33}$; 9 out of 10 animals given rMVAonly vaccines ${ }^{35}$ (R. R. Amara et al., unpublished observations); 3 out of 3 animals given a DNA/Ad5 vaccine; and three out of three animals given an Ad5-only vaccine ${ }^{34}$ had reduced post-challenge viraemia to the lower limit of detection (<1000 copies of viral RNA per ml of plasma). None of the 26 control animals in these vaccine trials similarly controlled infection. Challenges were administered between six weeks $s^{32,34,35}$ and seven months $\mathrm{s}^{33}$ after immunization by both intravenous $\mathrm{s}^{32,34,35}$ and mucosal routes $^{33,117}$ (R. R. Amara et al., unpublished observations). The control of viraemia has been long lasting; so far, all animals with consistent control of their infection in the first six months have maintained this control. HIV-1infected patients with $<1000$ copies of viral RNA per ml of plasma are LONG-TERM NON-PROGRESSORS ${ }^{37}$ and tend not to transmit their infections ${ }^{39}$. So, although these vaccines do not prevent infection, they provide considerable hope for the improved survival of those who become infected and for reduced transmission of the epidemic.

\section{New technologies and vectors}

The successful vaccines have all been based on recombinant technologies that have been developed since the onset of the AIDS epidemic - DNA vaccines and live viral vectors. The first reports of the use of live viral vectors were published in 1982 (REFS 40,41) and the first reports of DNA-based immunizations came a decade later ${ }^{42-44}$. Both of these technologies have blossomed because of their ease of development and the practical power they bring to the development of subunit vaccines that are expressed in cells. Both, however, have had to undergo development for effective use against HIV-1 (BOX 2).

DNA vaccines for HIV-1. Several groups are developing DNA vaccines for HIV-1, and the first DNA vaccines to be tested in humans were HIV-1 vaccines ${ }^{45}$. The primary limitation of DNA vaccines has been the difficulty in achieving sufficient uptake and expression of DNA to induce a robust immune response. The problem of achieving high levels of gene expression has been compounded for DNA vaccines for HIV-1 because of the inefficient expression of HIV-1 messenger RNAs outside of the context of the HIV-1 genome. HIV-1 expresses mRNAs that encode structural and regulatory proteins by the subgenomic splicing of a single transcript. The HIV regulatory protein Rev regulates the splicing and movement of HIV-1 transcripts by binding to a cis-acting target, the Rev response element (RRE), which is present in unspliced and partially spliced HIV-1 mRNAs ${ }^{46}$. One way in which DNA vaccines have achieved high levels of HIV-1 protein expression is the use of Rev and the RRE to facilitate the expression of HIV-1 mRNAs. Rev-dependent subgenomic splicing can be used to express multiple HIV-1 proteins from single transcripts ${ }^{33}$ (FIG. 3), and has the potential for expressing non-infectious virus-like particles ${ }^{47}$. It can also achieve high levels of gene expression. However, even higher levels of HIV-1 gene expression can be achieved by the optimization of HIV-1 genes for the codons that are used most frequently in human cells ${ }^{48}$. CODON-OPTIMIZED sequences typically express single gene products ${ }^{32}$ or fusion proteins ${ }^{49}$ (FIG. 3 ) and achieve exceptionally high levels of gene expression by using all transcripts for a single, efficiently translated mRNA. Most codon-optimized vaccines have focused on the groupspecific antigen (Gag) protein, a primary target for $\mathrm{CD}^{+} \mathrm{T}$ cells in long-term non-progressors ${ }^{50}$. At present, most DNA vaccines are used at doses of several mg of DNA, which would require the production of about one litre of bacterial culture per dose of vaccine.

Other approaches to increasing the efficiency of DNA vaccines have focused on genetic adjuvants ${ }^{51}$, conventional adjuvants ${ }^{34}$, MICROSPHERES ${ }^{52}$ and in vivo electroporation ${ }^{53}$. So far, conventional adjuvants, such as alum 


\begin{tabular}{|c|c|c|c|c|c|c|c|}
\hline Vaccine & $\begin{array}{l}\text { Priming } \\
\text { immunogen }\end{array}$ & $\begin{array}{l}\text { Booster } \\
\text { immunogen }\end{array}$ & $\begin{array}{l}\text { SHIV-89.6P } \\
\text { challenge }\end{array}$ & $\begin{array}{l}\text { Control of } \\
\text { challenge } \\
\text { (controlled/total)* }^{*}\end{array}$ & Comment & $\begin{array}{l}\text { Status of } \\
\text { development } \\
\text { for humans }\end{array}$ & References \\
\hline $\begin{array}{l}\text { IL-2- } \\
\text { adjuvanted } \\
\text { DNA }\end{array}$ & $\begin{array}{l}5 \text { mg of codon- } \\
\text { optimized Gag DNA } \\
+5 \text { mg of codon- } \\
\text { optimized SHIV-89.6P } \\
\text { Env DNA, followed } \\
2 \text { days later by } 5 \text { mg } \\
\text { of IL-2-lg DNA. } \\
\text { Delivered i.m. at } \\
\text { weeks } 0 \text { and } 4\end{array}$ & $\begin{array}{l}5 \text { mg of } \\
\text { codon-optimized } \\
\text { SIV Gag DNA + } \\
5 \text { mg of codon- } \\
\text { optimized SHIV- } \\
\text { 89.6P Env DNA. } \\
\text { Delivered at } \\
\text { weeks } 8 \text { and } 40\end{array}$ & $\begin{array}{l}\text { i.v. at } 6 \text { weeks } \\
\text { after last booster }\end{array}$ & $\begin{array}{l}\text { Vaccine: } 4 / 4 \\
\text { Control: } 0 / 8\end{array}$ & $\begin{array}{l}\text { Good protection } \\
\text { of CD4 } 4^{+} T \text { cells. } \\
\text { Success also } \\
\text { achieved in } 3 / 4 \\
\text { animals by twice } \\
\text { daily innoculations } \\
\text { of IL-2-Ig protein } \\
\text { for } 1-14 \text { days after } \\
\text { DNA vaccination }\end{array}$ & $\begin{array}{l}\text { Being developed } \\
\text { for phase I trials } \\
\text { in humans }\end{array}$ & 9,26 \\
\hline $\begin{array}{l}\text { DNA- } \\
\text { rMVA }\end{array}$ & $\begin{array}{l}2.5 \mathrm{mg} \text { or } 0.25 \mathrm{mg} \\
\text { of SHIV-89.6 } \\
\text { Gag-Pol-Env DNA. } \\
\text { Delivered i.d. } \\
\text { or i.m. at weeks } \\
0 \text { and } 8\end{array}$ & $\begin{array}{l}2 \times 10^{8} \text { pfu of } \\
\text { SHIV-89.6 } \\
\text { Gag-Pol-Env rMVA. } \\
\text { Delivered i.d. and i.m. } \\
\text { at week } 24\end{array}$ & $\begin{array}{l}\text { i.r. at } 7 \text { months } \\
\text { after last booster }\end{array}$ & $\begin{array}{l}2.5 \text { mg i.d. DNA } \\
\text { prime: } 13 / 14 \\
0.25 \text { mg i.d. } \\
\text { DNA prime: } 6 / 6 \\
\text { 2.5. mg i.m. } \\
\text { DNA prime: } 6 / 6 \\
0.25 \text { mg i.m. } \\
\text { DNA prime: } 5 / 6 \\
\text { Control: } 0 / 6\end{array}$ & $\begin{array}{l}\text { Good protection } \\
\text { of CD4 }{ }^{+} \text {T cells } \\
\text { Control has. } \\
\text { improved with } \\
\text { time (at present, } \\
1.5 \text { years after } \\
\text { challenge) }\end{array}$ & $\begin{array}{l}\text { Gag-Pol-Env } \\
\text { subtype B DNA and } \\
\text { rMVA to enter separate } \\
\text { phase I trials in } 2002 \text {. } \\
\text { Subtype AG and C DNAs } \\
\text { and rMVAs being made } \\
\text { for a trivalent A + B + C } \\
\text { vaccine }\end{array}$ & 20 \\
\hline rMVA only & $\begin{array}{l}1 \times 10^{8} \text { pfu of } \\
\text { Gag-Pol rMVA } \\
+1 \times 10^{8} \text { pfu of } \\
\text { SHIV-89.6 Env rMVA. } \\
\text { Delivered i.m. at } \\
\text { weeks } 0 \text { and } 4\end{array}$ & $\begin{array}{l}1 \times 10^{8} \text { pfu of } \\
\text { Gag-Pol rMVA } \\
+1 \times 10^{8} \text { pfu of } \\
\text { SHIV-89.6 Env rMVA. } \\
\text { Delivered i.m. at } \\
\text { week } 21\end{array}$ & $\begin{array}{l}\text { i.v. at } 6 \text { weeks } \\
\text { after last booster }\end{array}$ & $\begin{array}{l}\text { Vaccine: } 3 / 4 \\
\text { Control: } 0 / 4\end{array}$ & $\begin{array}{l}\text { Some loss of } \\
\text { CD4 }{ }^{+} T \text { cells }\end{array}$ & & 22 \\
\hline rMVA only & $\begin{array}{l}2 \times 10^{8} \text { pfu of } \\
\text { SHIV-89.6 } \\
\text { Gag-Pol-Env rMVA. } \\
\text { Delivered i.d. and i.m. } \\
\text { at weeks } 0 \text { and } 8\end{array}$ & $\begin{array}{l}2 \times 10^{8} \text { pfu of } \\
\text { SHIV-89.6 } \\
\text { Gag-Pol-Env rMVA. } \\
\text { Delivered i.d. and i.m. } \\
\text { at week } 24\end{array}$ & $\begin{array}{l}\text { i.r. at } 7 \text { months } \\
\text { after last booster }\end{array}$ & $\begin{array}{l}\text { Vaccine: } 6 / 6 \\
\text { Control: } 0 / 6\end{array}$ & $\begin{array}{l}\text { Good protection } \\
\text { of CD4+ T cells. } \\
\text { Exceptionally } \\
\text { tight control } \\
\text { of the infection }\end{array}$ & $\begin{array}{l}\text { HIV-1 subtype B } \\
\text { Gag-Pol-Env rMVA to } \\
\text { enter phase I trials in } 2002 \\
\text { Subtype AG and C rMVAs } \\
\text { being made for a trivalent } \\
A+B+C \text { vaccine }\end{array}$ & $\begin{array}{l}23 \\
2 . \\
\text { S. }\end{array}$ \\
\hline DNA-Ad5 & $\begin{array}{l}5 \text { mg SIV Gag DNA } \\
\text { in CRL1005 adjuvant. } \\
\text { Delivered i.m. at } \\
\text { weeks } 0,4 \text { and } 8\end{array}$ & $\begin{array}{l}1 \times 10^{11} \text { particles } \\
\text { of Ad5-SIV Gag. } \\
\text { Delivered i.m. at } \\
\text { week } 32\end{array}$ & $\begin{array}{l}\text { i.v. at } 6 \text { weeks } \\
\text { after last booster }\end{array}$ & $\begin{array}{l}\text { Vaccine: } 3 / 3 \\
\text { Control: } 0 / 8\end{array}$ & $\begin{array}{l}\text { Long-lasting } \\
\text { CD8+ T-cell } \\
\text { response. } \\
\text { Protection with } \\
\text { Gag alone }\end{array}$ & $\begin{array}{l}\text { HIV-1 subtype B Gag } \\
\text { DNA in phase I trials }\end{array}$ & 21 \\
\hline Ad5 only & $\begin{array}{l}1 \times 10^{11} \text { particles } \\
\text { of Ad5 SIV Gag. } \\
\text { Delivered at weeks } \\
0 \text { and } 6\end{array}$ & $\begin{array}{l}1 \times 10^{11} \text { particles } \\
\text { of Ad5 SIV Gag. } \\
\text { Delivered i.m. at } \\
\text { week } 32\end{array}$ & $\begin{array}{l}\text { i.v. at } 12 \text { weeks } \\
\text { after last booster }\end{array}$ & $\begin{array}{l}\text { Vaccine: } 3 / 3 \\
\text { Control: } 0 / 6\end{array}$ & $\begin{array}{l}\text { Long-lasting acute } \\
\text { CD } 8^{+} \text {T-cell response } \\
\text { with }>1 \text { peak in } 3 / 3 \\
\text { animals. Protection } \\
\text { with Gag alone. } \\
\text { Problem of } \\
\text { pre-existing immunity } \\
\text { in } \sim 45 \% \text { of US } \\
\text { population }\end{array}$ & $\begin{array}{l}\text { HIV-1 subtype B } \\
\text { Gag-Ad5 in phase I } \\
\text { trials }\end{array}$ & 21 \\
\hline
\end{tabular}

Ad5, adenovirus 5; Env, envelope protein; Gag, group-specific antigen; IL-2, interleukin-2; IL-2-lg, IL-2 fused to the heavy chain of immunoglobulin; i.d., intradermal; i.m., intramuscular; i.r., intrarectal; i.v., intravenous; pfu, plaque-forming unit; Pol, polymerase; rMVA, recombinant modified vaccinia Ankara; SHIV-89.6P, pathogenic hybrid of SIV and HIV; SIV, simian immunodeficiency virus. ${ }^{*}$ Control of challenge is defined as a reduction of the level of viral RNA to $\leq 1000$ copies per ml of plasma.

and block copolymers ${ }^{34}$, have not increased the efficacy of DNA-based vaccines sufficiently to induce protective immunity for immunodeficiency viruses ${ }^{34}$. However, a new adjuvant, IL-2, fused to the heavy chain of immunoglobulin (Ig) to increase the half-life of IL-2 activity $^{54}$, primes protective immunity both when the IL-2-Ig is delivered as a protein (twice a day for 14 days after DNA immunization) or a genetic adjuvant (single inoculation two days after DNA immunization) $)^{32}$. In mouse models, augmentation of T-cell immunity required administration of the IL-2 genetic adjuvant after, rather than with, DNA immunization. The requirement for administering the IL-2 adjuvant after the DNA-based immunization is not understood, but might be due to the ability of IL-2 to increase the number of responding $\mathrm{T}$ cells that enter the long-term memory pool ${ }^{54}$.
Live vaccine vectors for $H I V$-1. Virtually every virus with a molecularly cloned sequence that can be used to express an infectious agent has undergone at least some development as a candidate HIV-1 vaccine. Current live viral vectors that are being developed for use against immunodeficiency viruses include several avian and mammalian poxviruses ${ }^{33,35}$ (see http://www.iavi.org/ trialsdb and http://www.hvtn.org/trials), replicationdefective adenoviruses ${ }^{34}$, alphaviruses ${ }^{55}$, rhabdoviruse $^{56}$, herpesviruses ${ }^{57}$, adeno-associated virus ${ }^{58}$ and picornaviruses $^{59}$. Bacterial vectors with the promise of easy oral delivery to facilitate worldwide administration are undergoing development ${ }^{60}$. Each of these vector systems is unique with respect to the size of the vaccine inserts that can be carried, the host range of cells that will be infected, the host pro-inflammatory responses 


\section{Box 2 | New and improved technologies}

\section{DNA vaccines:}

- $\operatorname{Rev}(\mathrm{HIV}-1$ regulatory protein)-dependent subgenomic splicing

- codon optimization

- genetic adjuvants

- conventional adjuvants

- improved expression cassettes

Live viral vectors:

- extension to several families of viruses

- increased insert sizes

- development of replication-defective agents

- elimination of immune-evasion responses

- improved expression cassettes.

Heterologous prime-boost protocols

- DNA-recombinant modified vaccinia Ankara (rMVA)

- DNA-adenovirus 5 (Ad5)

stimulated and the immune-evasion strategies of the vector (TABLE 2).

The two viral vectors that have had the most preclinical success are MVA and Ad5 (TABLE 1). Both MVA and Ad5 vectors have the safety feature of being replication defective in primate cells. Replication-competent poxviruses and adenoviruses can cause disseminated disease in immunocompromised individuals. The replication of MVA in humans was attenuated by $>500$ passages in chick-embryo fibroblasts ${ }^{61,62}$, during which time MVA acquired six large genomic deletions ${ }^{63}$. These deletions eliminated host-range genes, as well as immuneevasion genes that encode soluble receptors for IFN $-\gamma$, IFN- $\alpha / \beta$, TNF and CC-chemokines ${ }^{64}$, but did not compromise the ability of MVA to grow in chicken cells. Molecular biologists deleted the E1 and E3 regions of the adenovirus genome from the Ad5 vector. The E1 deletion eliminated early functions crucial to viral replication and rendered the vector replication defective, except when grown in cells that provided $\mathrm{E} 1$ functions in trans. Both the E1 and E3 deletions eliminated immune-evasion genes. E1A proteins interfere with the antiviral activity of IFNs ${ }^{65}$ by blocking the activation of IFN response factors ${ }^{66,67}$. The $\mathrm{E} 3$ region inhibits the cytolysis of infected cells by $\mathrm{CD}^{+} \mathrm{T}$ cells ${ }^{68,69}$ and $\mathrm{TNF}^{70,71}$. The growth of MVA in chick-embryo fibroblasts poses no risk for the generation of a replicationcompetent virus for humans, because the host-range mutations map to more than one deletion ${ }^{72}$. By contrast, the growth of Ad5 in E1-expressing cells poses some risk of the acquisition of $\mathrm{E} 1$ sequences by recombination; these risks, however, can be minimized in the design of HELPER CELL lines ${ }^{73}$. MVA can be grown in chickembryo fibroblasts to titres of $1 \times 10^{11}-5 \times 10^{11}$ plaqueforming units (pfu) per $1 \times 10^{9}$ cells. In preclinical trials, doses of up to $2 \times 10^{8} \mathrm{pfu}$ have been used (TABLE 1). The adenovirus vectors are likely to be produced in helper cell lines, such as PRC6, which produce titres of
$1 \times 10^{13}-5 \times 10^{13}$ particles $\left(1 \times 10^{11}-5 \times 10^{11} \mathrm{pfu}\right)$ per $1 \times$ $10^{9}$ cells. In preclinical trials, doses of $1 \times 10^{11}$ particles have been used (TABLE 1).

Both MVA and Ad5 can express high levels of HIV-1 genes. The block in the replication of MVA occurs after the expression of the viral late genes but before virion morphogenesis ${ }^{74}$. The unimpaired late as well as early viral-protein synthesis, even in non-permissive human cells, accounts in part for the usefulness of MVA as a safe but efficient expression vector. The promoters that are used for HIV-1 expression in MVA at present have been designed to be active in early as well as late phases of poxvirus infections, and support high levels of continuous insert expression ${ }^{75}$. Because MVA produces its mRNA in the cytoplasm of cells, recombinant HIV-1 genes do not have to be engineered to overcome Rev dependence for splicing. MVA, by virtue of its size, also offers the opportunity for the expression of large inserts, and easily accommodates the expression of several HIV-1 proteins by the expression of different HIV-1 mRNAs from different promoters. In contrast to MVA, Ad5 expresses its genes in the nucleus. Transcription cassettes, which are modelled at present on those used for DNA vaccines, are placed in the position of the deleted E1 gene. Because of the nuclear expression, HIV-1 genes need to be codon-optimized to avoid Rev dependence. Size constraints over what can be placed in the E1 region limit expression to promoter-plus-insert sequences of about $5 \mathrm{~kb}$, and favour the development of single-gene HIV-1 vaccines.

Both MVA and Ad5 have a broad host range for human cells, and both stimulate the production of pro-inflammatory cytokines that augment immune responses. Adenovirus vectors lead to efficient antigen presentation by infecting immature dendritic cells and causing their maturation without polarizing the T-helper response $\mathrm{e}^{76,77}$. MVA infections mobilize innate immune responses by stimulating the production of high levels of type I interferon ${ }^{64}$. Adenoviruses are highly inflammatory; they stimulate the production of TNF, IL-1 and IL-6 (REF. 78). Adenoviruses can cause tumours in animal models. This, however, has not been a concern for Ad5, because of the deletion of the E1 region of the genome that supports tumour induction.

A major limitation of live-vector vaccines is the presence of pre-existing immunity to the vector. About $45 \%$ of the US population now has neutralizing antibodies that are specific for Ad5 (REF. 79). Older people, who were vaccinated against smallpox, will have pre-existing immunity for MVA; an immunity that would become universal if vaccinations for smallpox were to become routine to counter the threat of bioterrorism. However, the rMVA vaccines could serve a dual purpose immunization against smallpox and HIV-1. This potential merits investigation, because the dual vaccine would have the practical, as well as economic, advantage of achieving two immunizations with one vaccine, and could provide a smallpox vaccine with a lower incidence of adverse effects than the current vaccine ${ }^{80}$. Pre-existing immunity can be overcome by higher doses of vaccine,
A cell line that provides esse viral functions for the growth of a defective viral vector. 


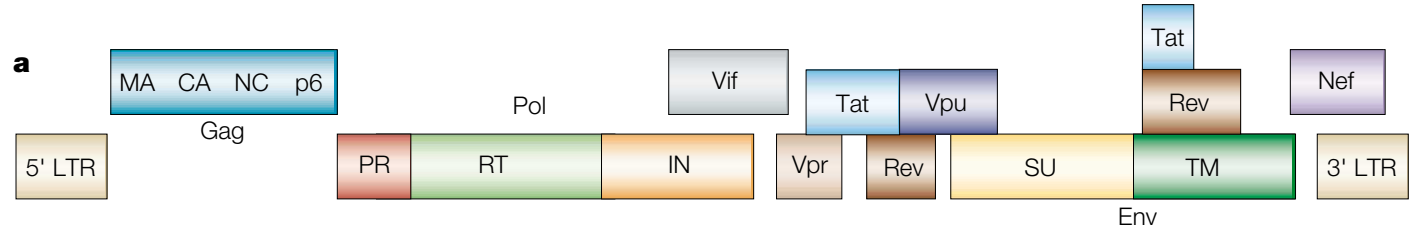

b

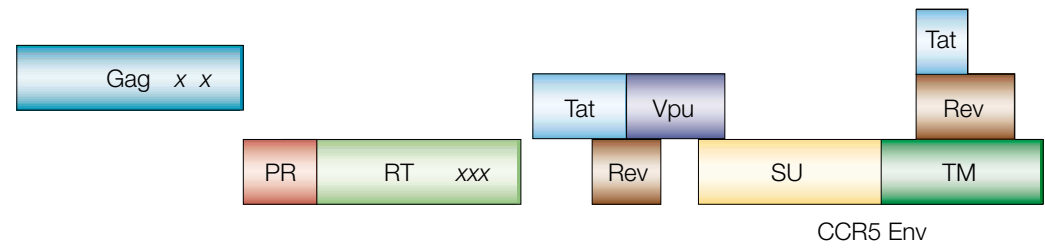

C

\begin{tabular}{|l|l|l|l|}
\hline Gag & PR & RT & IN \\
\hline
\end{tabular}

Figure 3 | Two strategies for HIV DNA vaccine inserts. a | Depiction of the nine open reading frames - Gag, Env, Pol, Tat, Rev, $\mathrm{Vpu}, \mathrm{Vif}, \mathrm{Vpr}$ and Nef -in the HIV-1 genome. b| Example of the expression of several proteins from a single DNA by HIV regulatory protein (Rev)-dependent subgenomic splicing. The construct is the HIV-1 DNA vaccine that we are advancing into human trials. ' $X$ ' denotes a safety mutation that inactivates reverse transcriptase or the zinc fingers for packaging viral RNA. c $\mid$ Example of the expression of a codon-optimized fusion protein. This DNA vaccine expresses the largest number of sequences among current codon-optimized vaccines, and was constructed by deleting the frameshift between the genes that encode group-specific antigen (Gag) and the viral enzymes protease (PR), reverse transcriptase (RT) and integrase (IN). The PR gene includes an inactivating mutation. The insert was developed at the National Institutes of Health Vaccine Research Center and is being advanced for phase I human trials ${ }^{49}$. CA, p24 capsid protein; Env, envelope protein; LTR, long terminal repeat; MA, p17 matrix protein; NC, p7 nucleocapsid protein; RT, p66/p51 reverse transcriptase; SU, gp120 surface envelope protein; TM, gp41 transmembrane envelope protein. vif, vpr, vpu and nef are viral accessory proteins; tat and rev are viral regulatory proteins.

and by heterologous PRIME-BOOST protocols. Higher doses of vaccine are a 'brute force' approach to immunizing in the presence of pre-existing immunity. Priming with an agent for which pre-existing immunity does not exist, such as DNA, establishes memory T cells that require the booster to achieve only sufficient infection to augment the primed immune response. Nevertheless, for both rMVA and Ad5 vaccines, a vector-naive population is the simplest and preferred population for vaccination.

Heterologous prime-boost protocols. A new and popular method for raising high frequencies of $\mathrm{T}$ cells is to combine DNA priming with live-vector boosters ${ }^{81-83}$. The remarkable efficiency of priming with DNA followed by boosting with a live vector is considered to be due to the DNA focusing the immune response on the vaccine antigens (as opposed to stimulating an immune response to vector, as well as vaccine, antigens). The livevector booster then enhances this immune response by expressing larger amounts of antigen than can be achieved with DNA alone and by the stimulation of a pro-inflammatory response that augments immunity. An example of the remarkable strength of T-cell, as well as antibody, responses that can be achieved by DNA priming followed by boosting with rMVA is shown in FIG. 4. In this example, both the DNA and the rMVA encoded SHIV Gag, polymerase (Pol) and Env proteins. The frequency of Gag-specific T cells was 20 times greater for the DNA prime followed by the rMVA booster than for rMVA priming and boosting. Similar phenomena are seen when DNA priming is combined with Ad5 boosting ${ }^{34}$. Also, one live vector can be used to prime a second live vector ${ }^{84}$.

\section{Lessons from comparative monkey trials}

Comparative vaccine trials in macaque models have been essential for the development of the current promising vaccines, and have been conducted by our own group ${ }^{33,85,86}$, as well as the groups of Letvin ${ }^{32,35}$ and $\mathrm{Merck}^{34}$. One of the most encouraging aspects of these trials is the extent to which findings in one trial have corroborated findings in other trials. Here, I summarize how our studies have pointed the way towards an AIDS vaccine, and highlight how these studies interface with those of others (BOX 3).

DNA alone does not protect. Our first trial clearly showed that DNA priming and boosting was not sufficient to induce protective immunity ${ }^{85}$. With the exception of one trial that used a highly avirulent HIV-1-challenge model in chimpanzee ${ }^{87}$, DNA immunizations alone, even with codon-optimized sequences ${ }^{32}$ with or without conventional adjuvants ${ }^{34}$, have raised poor protective immunity.

Poxvirus versus protein boosters. In our second trial, we combined DNA priming with envelope protein or poxvirus boosters to achieve higher titre immune responses ${ }^{86}$. This trial showed that poxvirus boosters 


\begin{tabular}{|c|c|c|c|c|c|c|c|c|}
\hline Vector & Example & $\begin{array}{l}\text { Insert } \\
\text { size }\end{array}$ & $\begin{array}{l}\text { Replication } \\
\text { competence }\end{array}$ & $\begin{array}{l}\text { Tissue } \\
\text { tropism }\end{array}$ & $\begin{array}{l}\text { Pro- } \\
\text { inflammatory }\end{array}$ & $\begin{array}{l}\text { Immune- } \\
\text { evasion } \\
\text { strategy }\end{array}$ & $\begin{array}{l}\text { Pre-existing } \\
\text { immune } \\
\text { responses }\end{array}$ & Comment \\
\hline $\begin{array}{l}\text { Mammalian } \\
\text { pox- } \\
\text { virus }^{80,103}\end{array}$ & $\mathrm{MVA}^{33,35}$ & $>10 \mathrm{~kb}$ & $\begin{array}{l}\text { Replicates } \\
\text { in chicken, but } \\
\text { not primate, } \\
\text { cells }^{72}\end{array}$ & $\begin{array}{l}\text { Broad, } \\
\text { including } \\
\text { dendritic } \\
\text { cells }\end{array}$ & Type 1 IFN ${ }^{103}$ & $\begin{array}{l}\text { Soluble receptors } \\
\text { for IFN- } \gamma \text {, IFN- } \alpha / \beta \text {, } \\
\text { TNF and CC- } \\
\text { chemokines } \\
\text { lost during } \\
\text { attenuation } 64\end{array}$ & $\begin{array}{l}\text { Older humans } \\
\text { and health } \\
\text { workers who } \\
\text { have been } \\
\text { vaccinated } \\
\text { against } \\
\text { smallpox }\end{array}$ & $\begin{array}{l}\text { High-level insert expression } \\
\text { and immunogenicity owing } \\
\text { to its expression of early, as } \\
\text { well as late, vaccinia genes }{ }^{104} \text {. } \\
\text { Scrambled partial Gag } \\
\text { plus } 23 \text { CD8 epitopes } \\
\text { for subtype A in phase I } \\
\text { trials in England and Kenya }{ }^{102} \text {. } \\
\text { Added CD8 epitopes include } \\
\text { ones recognised by } 17 \\
\text { different HLA types }\end{array}$ \\
\hline $\begin{array}{l}\text { Mammalian } \\
\text { pox- } \\
\text { virus }^{80,103}\end{array}$ & NYAC ${ }^{105}$ & $>10 \mathrm{~kb}$ & $\begin{array}{l}\text { Replication } \\
\text { competent }^{106}\end{array}$ & Broad & Type 1 IFN & $\begin{array}{l}\text { Deletion of a } \\
\text { complement- } \\
\text { binding protein } \\
\text { and an inhibitor } \\
\text { of serine } \\
\text { proteases }^{106}\end{array}$ & $\begin{array}{l}\text { Older humans } \\
\text { and health } \\
\text { workers who } \\
\text { have been } \\
\text { vaccinated } \\
\text { against smallpox }\end{array}$ & $\begin{array}{l}\text { Developed by deleting } \\
20 \text { genes from the } \\
\text { Copenhagen strain of } \\
\text { vaccinia virus }^{106}\end{array}$ \\
\hline $\begin{array}{l}\text { Avian } \\
\text { pox- } \\
\text { virus }^{107,108}\end{array}$ & ALVAC $^{95,109}$ & $>10 \mathrm{~kb}$ & $\begin{array}{l}\text { Replicates in } \\
\text { chicken, but } \\
\text { not primate, } \\
\text { cells }^{107}\end{array}$ & Broad & ND & ND & No & $\begin{array}{l}\text { ALVAC1521 expressing } \\
\text { HIV-1 Gag and PR from } \\
\text { subtype B and Env from } \\
\text { subtype E with/without a } \\
\text { gp120 boost to enter phase III } \\
\text { trials in Thailand in } 2002\end{array}$ \\
\hline $\begin{array}{l}\text { Adeno- } \\
\text { virus }^{110}\end{array}$ & Ad5 (REF. 34) & $<5 \mathrm{~kb}$ & $\begin{array}{l}\text { Requires } \\
\text { helper cells } \\
\text { that express E1 }\end{array}$ & $\begin{array}{l}\text { Broad, } \\
\text { including } \\
\text { immature } \\
\text { dendritic } \\
\text { cells }^{77}\end{array}$ & $\begin{array}{l}\text { TNF, } \\
\text { IL-1 and } \\
\text { IL-6 (REF. 78) }\end{array}$ & $\begin{array}{l}\text { Deletion of } \\
\text { adenoviral E1 } \\
\text { and E3 genes } \\
\text { that inhibit IFNs } \\
\text { and the cytolytic } \\
\text { activity of CD8+ } \\
\text { T cells during } \\
\text { construction }\end{array}$ & $\begin{array}{l}\text { 45\% of US } \\
\text { population } \\
\text { have neutralizing } \\
\text { antibody owing } \\
\text { to natural } \\
\text { infection }^{79}\end{array}$ & $\begin{array}{l}\text { Unusually long acute } \\
\text { phase for CD8+ T-cell } \\
\text { responses }\end{array}$ \\
\hline $\begin{array}{l}\text { Alpha- } \\
\text { virus }^{111}\end{array}$ & VEE $^{55}$ & $<5 \mathrm{~kb}$ & $\begin{array}{l}\text { Live-attenuated } \\
\text { and replication } \\
\text { defective }\end{array}$ & $\begin{array}{l}\text { Lymphoid } \\
\text { tissue, } \\
\text { including } \\
\text { dendritic } \\
\text { cells }\end{array}$ & ND & ND & $\begin{array}{l}\text { VEE-vaccinated } \\
\text { populations }\end{array}$ & $\begin{array}{l}\text { Replication-defective } \\
\text { VEE scheduled for phase I } \\
\text { safety trials in } 2002\end{array}$ \\
\hline $\begin{array}{l}\text { Rhabdo- } \\
\text { virus }^{112}\end{array}$ & $\begin{array}{l}\text { Vesicular } \\
\text { stomatitis } \\
\text { virus }^{56}\end{array}$ & $<5 \mathrm{~kb}$ & $\begin{array}{l}\text { Live- } \\
\text { attenuated }\end{array}$ & $\begin{array}{l}\text { Broad, } \\
\text { including } \\
\text { mucosal } \\
\text { tissues }\end{array}$ & ND & ND & $\begin{array}{l}\text { Some rural } \\
\text { workers }\end{array}$ & $\begin{array}{l}\text { Can be administered } \\
\text { intranasally }{ }^{56} \text {. Boosters } \\
\text { use different serotypes } \\
\text { to bypass vector-induced } \\
\text { immunity }{ }^{56}\end{array}$ \\
\hline $\begin{array}{l}\text { Herpes } \\
\text { virus }^{113}\end{array}$ & $\begin{array}{l}\text { Herpes } \\
\text { simplex } \\
\text { virus }^{57}\end{array}$ & $>5 \mathrm{~kb}$ & $\begin{array}{l}\text { Live- } \\
\text { attenuated } \\
\text { and replication } \\
\text { defective }\end{array}$ & $\begin{array}{l}\text { Epithelial } \\
\text { cells and } \\
\text { ganglia }\end{array}$ & ND & None deleted & $\begin{array}{l}\text { Most humans, } \\
\text { owing to } \\
\text { natural infections }\end{array}$ & $\begin{array}{l}\text { Presumed long-term } \\
\text { persistence of } \\
\text { immunizing vector as a } \\
\text { latent/re-activating infection }\end{array}$ \\
\hline $\begin{array}{l}\text { Adeno- } \\
\text { associated } \\
\text { virus }^{110}\end{array}$ & $\mathrm{AAV}^{58}$ & $<5 \mathrm{~kb}$ & $\begin{array}{l}\text { Replication } \\
\text { defective, } \\
\text { grown in } \\
\text { helper cell lines }\end{array}$ & $\begin{array}{l}\text { Determined } \\
\text { by helper } \\
\text { virus }\end{array}$ & ND & $\begin{array}{l}\text { Depends on } \\
\text { helper virus }\end{array}$ & $\begin{array}{l}\text { Humans } \\
\text { with natural } \\
\text { adenovirus } \\
\text { infections }\end{array}$ & $\begin{array}{l}\text { Integration into } \\
\text { host genome }\end{array}$ \\
\hline $\begin{array}{l}\text { Picorna- } \\
\text { virus }^{59}\end{array}$ & Poliovirus ${ }^{114}$ & $<2 \mathrm{~kb}$ & $\begin{array}{l}\text { Live- } \\
\text { attenuated }\end{array}$ & $\begin{array}{l}\text { Mucosal } \\
\text { tissues }\end{array}$ & ND & ND & $\begin{array}{l}\text { Humans } \\
\text { vaccinated } \\
\text { with poliovirus }\end{array}$ & $\begin{array}{l}\text { Demonstrated safety } \\
\text { in humans }\end{array}$ \\
\hline
\end{tabular}

Insert sizes are approximate and depend on the nature, as well as the size, of the insert. AAV, adenovirus-associated virus; Ad5, adenovirus 5; Ag, antigen; ALVAC, a canary poxvirus; Env, envelope protein; Gag, group-specific antigen; IFN, interferon; IL, interleukin; MVA, modified vaccinia Ankara; NYVAC, New York vaccinia virus; ND, not defined; PR, protease; TNF, tumour-necrosis factor; VEE, Venezuelan equine encephalitis virus.

GENE GUN

A device that uses compressed helium to bombard DNA-coated gold beads into cells. The beads are usually $1-2 \mu \mathrm{m}$ in diameter. were superior to Env boosters. DNA priming plus poxvirus boosters controlled the challenge in the absence of detectable levels of neutralizing antibody, a finding that indicated that protection was mediated by $\mathrm{T}$-cell responses. The poor ability of protein boosters to augment DNA-based immunizations has been reproduced in a study using Gag-Pol, as well as Env, protein boosters. In this trial, DNA alone provided better protection than DNA plus protein boosters ${ }^{88}$.
However, in a third trial that used DNA plus an IL-12 genetic adjuvant followed by Env protein boosters, the Env protein increased protection ${ }^{89}$.

Saline injection versus gene-gun inoculation. Our second trial tested whether priming could be achieved by GENE- GUN inoculation, which requires much less DNA than saline injections to raise immune responses ${ }^{90}$. This trial clearly showed that priming must be by saline 

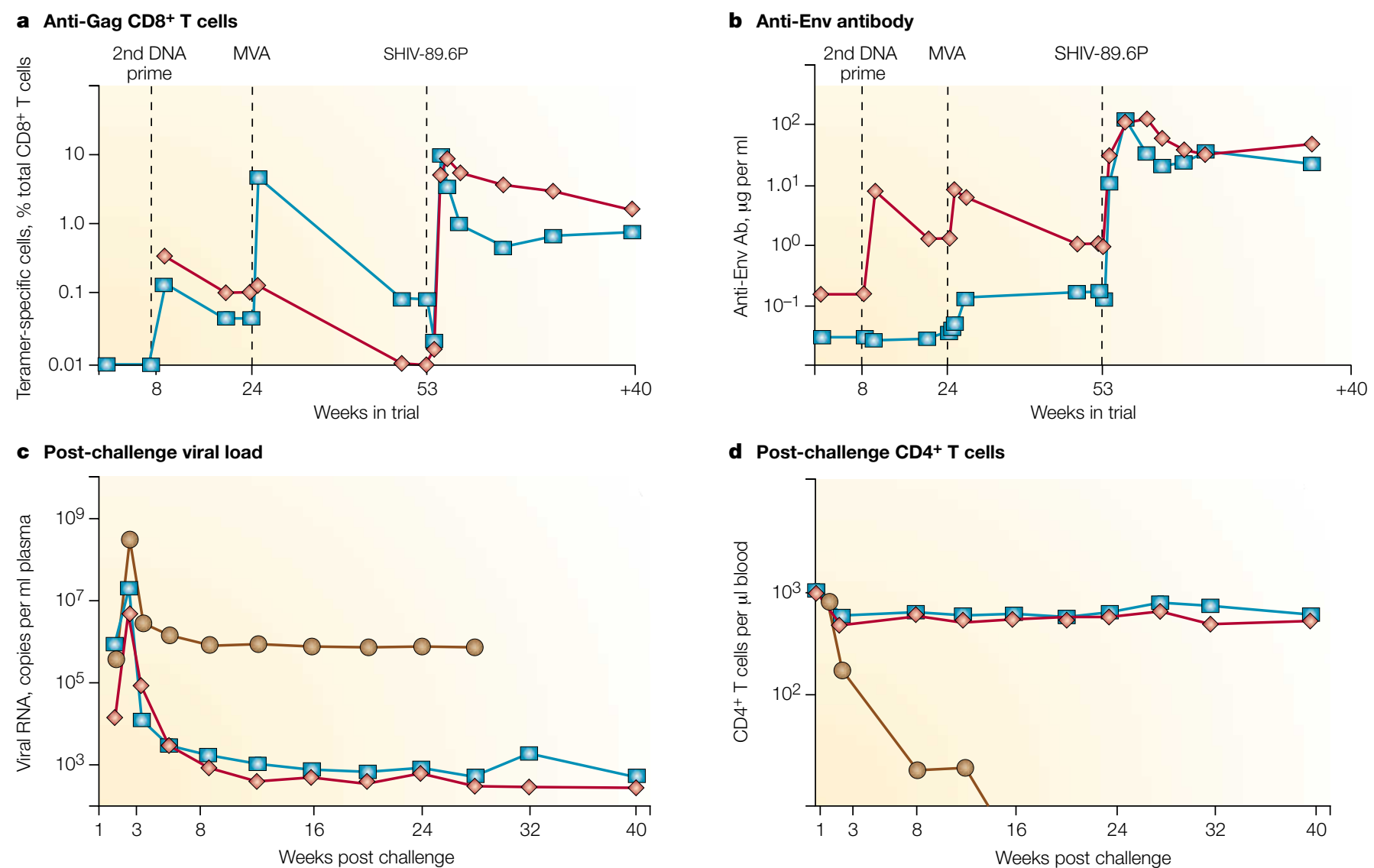

DNA priming and rMVA boosting $\diamond$ rMVA priming and boosting $\bigcirc$ Unvaccinated controls

\section{$\mathrm{T}_{\mathrm{H}} 1 / \mathrm{T}_{\mathrm{H}} 2$}

(T-helper cells type 1 and T-helper cells type 2). These two types of $\mathrm{T}$ cell have distinctive patterns of lymphokine production. In mouse models, $\mathrm{T}_{\mathrm{H}} 1$ cells produce IFN- $\gamma$ (which supports the production of complement-dependent antibodies and the activation of phagocytic defences), whereas $\mathrm{T}_{\mathrm{H}} 2$ cells produce IL- 4 (which supports the production of complement-independent antibodies and the activation of eosinophils and mast cells).

Figure 4 | Different patterns of immune responses, but similar patterns of SHIV-89.6P control in DNA-rMVA and rMVAonly immunized animals.

a | Group-specific antigen (Gag)-specific CD8 ${ }^{+} T$ cells; $\mathbf{b}$ | anti-envelope protein (Env) antibody (Ab); c | post-challenge viral loads; and $\mathbf{d} \mid$ post-challenge $C D 4^{+} T$ cells in vaccinated macaques. DNA-recombinant modified vaccinia Ankara (rMVA) immunizations consisted of $2.5 \mathrm{mg}$ of a Gag-Pol-Env DNA administered intradermally at weeks 0 and 8 , and $2 \times 10^{8}$ plaque-forming units (pfu) of a Gag-Pol-Env-rMVA administered intradermally and intramuscularly at week 24. Recombinant MVA immunizations consisted of $2 x$ $10^{8}$ pfu of a Gag-Pol-Env-rMVA administered intradermally and intramuscularly at weeks 0,8 and 24 . The simian immunodeficiency virus-HIV (SHIV-89.6P) challenge was delivered intrarectally seven months after the booster. Data are from REF. 33 and R. R. Amara et al., unpublished observations.

injection, not gene-gun delivery, of $\mathrm{DNA}^{86}$. In mouse models, saline injections of DNA tend to induce T-helper type $1\left(\mathrm{~T}_{\mathrm{H}} 1\right)$ cells, whereas gene-gun inoculations tend to induce $\mathrm{T}_{\mathrm{H}} 2$ cells ${ }^{91}$. We have proposed that the failure of gene-gun priming is due to the induction of $\mathrm{T}_{\mathrm{H}} 2$, and not $\mathrm{T}_{\mathrm{H}} 1$, cells, and that $\mathrm{T}_{\mathrm{H}} 1$-supported immune responses are more effective than $\mathrm{T}_{\mathrm{H}} 2$ supported immune responses for controlling infections with immunodeficiency viruses. The failure of gene-gun priming to raise protective immune responses, despite its ability to prime high titres of $\mathrm{CD} 8^{+} \mathrm{T}$ cells, has been shown in other experiments using SIV challenges in macaques $^{92}$, and for a DNA vaccine experiment using a Mycobacterium tuberculosis challenge in mice ${ }^{93}$.

Gag-Pol-Env versus Gag-Pol immunogens. In our third trial, the ability of Gag-Pol versus Gag-Pol-Env DNA and rMVA immunogens to raise protection was compared $^{117}$. This trial clearly showed that including Env in the immunizations increased protection. Both vaccines raised similar high frequencies of Gag-specific T cells. However, the Gag-Pol vaccine controlled the challenge in only 7 out of 12 animals, compared with 12 out of 12 animals for the Gag-Pol-Env vaccine. This result is in contrast to results of the Ad5-Gag vaccine, for which consistent control, albeit in a small group, was achieved in the absence of Env protein ${ }^{34}$. At the time of challenge, the Ad5-immunized animals had higher levels of specific T cells ( $1-25 \%$ of total CD8 ${ }^{+} \mathrm{T}$ cells) than our DNA/rMVA-immunized animals $\left(<1 \%\right.$ of total $\mathrm{CD}^{+}$ $\mathrm{T}$ cells $)^{33}$. This might have been the result of more prolonged expression of the Ad5 vaccine than the rMVA vaccine. Five out of six Ad5-immunized animals had two peaks in the number of Gag-specific T cells after immunization (which implies the continuing presence of the vector), in contrast to the single sharp peak in the number of Gag-specific T cells in DNA-rMVA- or rMVA-immunized animals ${ }^{34}$. Also, the SHIV-89.6P 


\section{Box 3 | Findings from our path towards a human vaccine}

1994-1996 (REF. 85)

- DNA alone does not protect

1997-1999 (REF. 86)

- DNA priming followed by poxvirus boosters is superior to DNA followed by protein boosters

- Saline injections, but not gene-gun delivery, of DNA prime protective immune responses

- Protective T cells control, rather than eliminate, infections

2000-2002

- DNA priming and recombinant modified vaccinia Ankara (rMVA) boosting is able to control a virulent mucosal challenge ${ }^{33}$

Other results that are unpublished at present (R. R. Amara et al. and S. Buge, unpublished observations) include:

- rMVA priming and boosting can control a virulent mucosal challenge

- Vaccines that express envelope protein (Env) are more effective than vaccines that express only group-specific antigen $(\mathrm{Gag})$ and polymerase $(\mathrm{Pol})$

- Alum-adjuvanted glycoprotein 120 (gp120) boosters do not improve protection

- Different vaccines induce different patterns of protective responses ${ }^{33}$

VIRAL SET POINT

The viral set point is the steadystate level of viral RNA that is established following the acute phase of infection. At present, viral set points are the best known indicators for how rapidly a patient will progress to AIDS.

CORRELATE OF PROTECTION An immune response that indicates that a vaccine will protect against a challenge infection. challenge in Ad5-immunized animals was administered 6-12 weeks after the final booster, much sooner than the challenge in our trials, which was given seven months after the final immunization. This difference in timing allowed less time for the long-lasting acute T-cell response in the Ad5-immunized groups to develop into a memory response. Together, these results indicate that Env is not essential for protection, but does provide an extra margin of safety. A role for Env, as well as Gag-Pol, in protective immunity against a SIV challenge has also been suggested in studies using recombinant poxviruses for priming and boosting ${ }^{94}$.

Recombinant gp120 protein boosters. Because protein boosters induce strong antibody responses, we tested whether adding Env glycoprotein 120 (gp120) to a DNA-rMVA immunization would increase protective efficacy. Unexpectedly, protection was less consistent in the animals that received gp 120 boosters than in those that received only the DNA-rMVA vaccinations. In these experiments, in collaboration with Janet McNicholl's group at the US Centers for Disease Control and Prevention, we delivered $300 \mu \mathrm{g}$ of SHIV-89.6 gp120 in alum with the second DNA immunization and the rMVA booster (S. Buge et al., unpublished observations). A poor ability of Env protein boosters to increase protective immunity has been found in trials in which $300 \mu \mathrm{g}$ of oligomeric gp140 or monomeric gp120 in QS21 (a $\mathrm{T}_{\mathrm{H}} 1$ adjuvant) were given as boosters for poxvirus immunizations ${ }^{95,96}$.

Live vectors alone. Despite the fact that DNA priming followed by live-virus boosters induces much higher frequencies of $\mathrm{T}$ cells than priming and boosting with a live vector, both rMVA and Ad5 priming and boosting have been shown to be able to control challenge with pathogenic SHIV-89.6 $\mathrm{P}^{34,35}$ (TABLE 1). In these immunizations, control of the VIRAL SET POINT Occurs in the presence of lower frequencies of antiviral $\mathrm{CD} 8^{+}$ $\mathrm{T}$ cells than are raised by the heterologous prime-boost protocols. In the case of the rMVA-only immunized animals, which expressed Gag-Pol and Env, Gag-specific $\mathrm{T}$ cells were present at ten times lower levels and antiEnv antibody at ten times higher levels at the time of challenge than in the DNA-rMVA-vaccinated animals (FIG. 1). So, in the rMVA-only-vaccinated animals, protection occurred in the presence of a very different balance of antibody and T-cell responses than in the DNA-rMVA-vaccinated animals; current opinion would have predicted that this balance would not be favourable for protection. Nevertheless, irrespective of current opinion, the ability to use a single-modality immunization would be beneficial for an effective campaign to control the AIDS epidemic. At present, singlemodality avian poxvirus immunizations are entering phase III clinical trials (TABLE 2). In the preclinical trials that we have conducted, fowlpox vectors have not shown as much promise as MVA vectors - administration of a mixture of three fowlpox vectors expressing Gag-Pol, Env or Nef failed to control an avirulent SHIV-IIIb challenge ${ }^{86}$.

Control rather than elimination of infection. At the end of our second vaccine trial, we transfused blood from the three macaques that had controlled a series of challenge infections to below our level of detection ${ }^{86}$. Remarkably, blood from one of the three monkeys transmitted the SHIV-IIIb infection that it had been exposed to six months before the transfusion, which we had never detected by reverse transcriptase (RT)-PCR (even shortly after the SHIV-IIIb challenge). This transmission of virus indicated the establishment of longterm proviral DNA in a 'protected' DNA-poxvirusimmunized animal. The presence of long-term proviral DNA means that a challenge virus that has been controlled by a cellular immune response has the potential for re-emergence, escape and the induction of immunodeficiency. Indeed, this has happened in one of the eight monkeys that originally controlled its SHIV89.6P challenge infection after IL-2-augmented DNA immunizations ${ }^{38}$.

\section{Decisions for efficacy trials}

The Holy Grail for the development of an AIDS vaccine has been the identification of a CORRELATE OF PROTECTION to use as a surrogate for raising protective immunity. Initially, AIDS researchers focused on neutralizing antibodies as the correlate. The pendulum then swung to the antiviral activities of $\mathrm{CD} 8^{+} \mathrm{T}$ cells and the raising of protective $\mathrm{T}$ cells ${ }^{19,97}$. Our experiments that compare Gag-Pol with Gag-Pol-Env immunizations clearly show that the frequencies of Gag-specific $\mathrm{CD}^{+} \mathrm{T}$ cells that can control the challenge in Gag-Pol-Env-immunized animals are not sufficient to control the challenge in Gag-Pol-immunized animals ${ }^{117}$. Both our own experiments and those of Merck show that different levels of T cells, at least those in peripheral blood, are associated with protection by homologous, as opposed to 
NON-TRANSMITTERS

HIV-1-infected humans who do

not transmit their infection

through homosexual or

heterosexual activity. These

individuals typically have levels

of viral RNA in their blood of

$<1000$ copies per $\mathrm{ml}$

SUBUNIT VACCINE

Subunit vaccines encode

portions of a pathogen only. heterologous, prime-boost protocols ${ }^{34}$ (FIG. 1). So, despite an increasing ability to accurately quantify cellular and humoural immune responses, a single correlate for protection has remained elusive, with different vaccines inducing different balances of cellular and humoural immune responses; the only true marker of protective capacity remains success in efficacy trials.

To decide which vaccines are to enter efficacy trials in humans, we will be asking how well our animal models predict protection in humans ${ }^{98}$. In our animal models, we use high challenge doses that infect every animal at the first exposure. By contrast, during the natural transmission of HIV-1, the low concentrations of HIV-1 in bodily fluids achieve successful transmission for only one in several hundred heterosexual acts or needle-stick exposures ${ }^{99}$. In our animal models, SHIV-89.6P establishes steady-state levels of viral RNA between $1 \times 10^{5}$ and $1 \times 10^{6}$ copies per $\mathrm{ml}$ of blood, and causes AIDS in most infected animals within six months ${ }^{32-34}$. In humans, most HIV-1 infections establish steady-state levels of viral RNA between $1 \times 10^{4}$ and $1 \times 10^{5}$ copies per $\mathrm{ml}$ of blood, and take ten or more years to develop into AIDS $^{37}$. For HIV-1 infections in the United States, a 10-100-fold reduction in virus set-point would place the vast majority of infections in the long-term non-progressor/ NON-TRANSMITTER category ${ }^{37,39}$. The current promising vaccines are achieving 1,000-10,000-fold reductions in viral set points (TABLE 1). If reductions in the titres of SHIV-89.6P in macaques reflect the magnitude of reductions that will be achieved by comparable HIV-1 vaccines in humans, these vaccines hold considerable hope for providing true benefit.

\section{Timeline for human trials}

Many years are required to take a vaccine from demonstrated promise in preclinical trials through safety, dosing and efficacy testing in humans. The HIV-1 vaccines that are now in phase III efficacy trials (two bivalent formulations of gp120 envelope proteins ${ }^{100}$ ) entered phase I/II human testing in 1997, and efficacy trials in the United States in 1998 and in Bangkok in 1999, which will be completed in 2002 and 2003, respectively ${ }^{101}$. Although many consider that these protein SUBUNIT VACCINES will not be highly successful because of their poor ability to raise $\mathrm{CD}^{+} \mathrm{T}$ cells, the trials have been crucial to the overall development of an AIDS vaccine; by both defining the efficacy of the gp120 subunit approach and setting precedents for future trials. A candidate vaccine that is about to enter phase III efficacy trials is based on a canarypox vector in the presence or absence of gp120 protein boosters (http://www.iavi.org/trialsdb). The criteria that have been set for this vaccine to proceed to efficacy trials are the raising of specific $\mathrm{CD}^{+} \mathrm{T}$ cells in at least $30 \%$ of volunteers at one or more time points (a cumulative cytotoxic T-lymphocyte response), lymphoproliferative responses in $60 \%$ of volunteers, and neutralizing antibodies specific for a lab-adapted strain in $70 \%$ of the volunteers. The codon-optimized Gag-DNA and Gag-Ad5 vectors of Merck's group are progressing well through phase I safety testing in humans. The International AIDS Vaccine Initiative is supporting an ongoing phase I trial for a codon-optimized CD8epitope-based DNA-rMVA vaccine ${ }^{102}$ in both England and Kenya, and is planning to test a vaccine that uses Venezuelan equine encephalitis virus as a vector in South Africa. The National Institutes of Health (NIH) Vaccine Research Center will have a modified and codon-optimized Gag-Pol DNA vaccine in phase I studies in 2002 (http://www.vrc.nih.gov/VRC/currenttrials.htm). Our Rev-dependent Gag-Pol-Env DNA vaccine and matched rMVA developed in the laboratory of Bernard Moss at the NIH will enter safety trials in 2002. Several other products are in, or nearing, phase I trials (http://www.iavi.org/trialsdb and http://www. hvtn.org/trials). From the initiation of phase I trials to the initiation of phase III trials takes at least two years. Efficacy trails for HIV-1 vaccines typically require three years and might require longer if control, rather than prevention, of infection is the endpoint. So, in the absolutely best of circumstances, the new and promising vaccines featured here will not be ready for licensure and general distribution until 2006-2007. We can only hope that these new vaccines that raise cellular immunity will be as effective in humans as in macaques.
1. Barre-Sinoussi, F. et al. Isolation of a T-lymphotropic retrovirus from a pa deiciency syndrome (AIDS) Science 220,868-871 (1983).

.- Popovic, M., Sarngadhan, M. G., Read, E. \& Gallo, Detection, isolation and continuous production of cytopath retroviruses (HTLV-III) from patients with AIDS and pre-AIDS Science 224, 497-500 (1984).

3. Ratner, L. et al. Complete nucleotide sequence of the AIDS virus, HTLV-III. Nature 313, 277-284 (1985).

4. Gorrlich, M. S. et. al. in Morbidity and Mortality Weekly Report 250-252 (US Centers for Disease Control and Report 250-252 (US Cent)
Prevention, Atlanta, 1981).

5. Kwong, P. D. et al. Structure of an HIV gp120 envelope glycoprotein in complex with the CD4 receptor and a neutralizing human antibody. Nature 393, 648-659 (1998).

6. Myszka, D. G. et al. Energetics of the HIV gp120-CD4 binding reaction. Proc. Natl Acad. Sci. USA 97, 9026-9031 (2000).

7. Parren, P. W., Moore, J. P., Burton, D. R. \& Sattentau, Q. J. The neutralizing antibody response to HIV-1: viral evasion and escape from humoral immunity. AIDS 13, S137-S162 (1999).

8. Finzi, D. \& Silliciano, R. F. Viral dynamics in HIV-1 infection. Cell 93, 665-671 (1998).
9. Finzi, D. et al. Latent infection of $C D 4^{+} T$ cells provides a mechanism for lifelong persistence of HIV-1, even in patients mechanism for lifelong persistence of HV-1, even in patients (1999).

10. Ramratnam, B. et al. The decay of the latent reservoir of replication-competent HIV-1 is inversely correlated with the extent of residual viral replication during prolonged antiretroviral therapy. Nature Med. 6, 82-85 (2000).

11. McCutchan, F. E. Understanding the genetic diversity of HIV-1. AIDS 14, S31-S44 (2000).

12. Korber, B. et al. Evolutionary and immunological implications of contemporary HIV-1 variation. Br. Med. Bull. 58, 19-42 (2001).

13. Gao, F. et al. Origin of HIV-1 in the chimpanzee Pan troglodytes troglodytes. Nature 397, 436-441 (1999).

14. Peeters, M. in HIV Molecular Immunology 2000 (eds Korber, B. et al.) I39-154 (Los Alamos National Laboratory, Los Alamos, 2000)

15. Preston, B. D. Reverse transcriptase fidelity and HIV-1 variation. Science 275, 228-229 (1997).

16. Ho, D. D. et al. Rapid turnover of plasma virions and CD4 Iymphocytes in HIV-1 infection. Nature 373, 123-126 (1995).
17. Evans, D. T. et al. Virus-specific cytotoxic T-lymphocyte responses select for amino-acid variation in simian immunodeficiency virus Env and Nef. Nature Med. 5, 1270-1276 (1999).

18. Yang O. O \& Walker. B. D. CD8 ${ }^{+}$cells in human immunodeficiency virus type I pathogenesis: cytolytic and noncytolytic inhibition of viral replication. Adv. Immunol. 66 273-311 (1997).

19. McMichael, A. J. \& Rowland-Jones, S. L. Cellular immune responses to HIV. Nature 410, 980-987 (2001).

20. Korber, B. et al. (eds) HIV Molecular Immunology 2000, II1-IIC32 (Theoretical Biology and Biophysics Group, Los Alamos, New Mexico, 2000).

21. Levy, J. A., Mackewicz, C. E. \& Barker, E. Controlling HIV pathogenesis: the role of the noncytotoxic anti-HIV response of CD8 ${ }^{+}$T cells. Immunol. Today 17, 217-224 (1996).

22. Rubbert, A. et al. Multifactorial nature of noncytolytic $C D 8^{+}$ T-cell-mediated suppression of HIV replication: $\beta$-chemokine-dependent and -independent Res. Hum. Retroviruses 13, 63-69 (1997).

23. Tomaras, G. D. et al. CD8 ${ }^{+}$T-cell-mediated suppressive activity inhibits HIV-1 after virus entry with kinetics indicating activity inhibits HIV-1 after virus entry with kinetics indicating
effects on virus gene expression. Proc. Natl Acad. Sci. USA effects on virus gene exp
$\mathbf{9 7}, 3503-3508$ (2000) 
24. Pal, R. et al. Inhibition of HIV- 1 infection by the $\beta$-chemokine MDC. Science 278, 695-698 (1997)

25. Garzino-Demo, A., DeVico, A. L., Cocchi, F. \& Gallo, R. C. $\beta$-chemokines and protection from HIV type 1 disease. AIDS Res. Hum. Retroviruses 14, S177-S184 (1998).

26. Phillips, R. E. et al. Human immunodeficiency virus genetic variation that can escape cytotoxic T-cell recognition. Nature 354, 453-459 (1991).

27. Borrow, P. et al. Antiviral pressure exerted by HIV-1-specific cytotoxic T lymphocytes (CTLs) during primary infection demonstrated by rapid selection of CTL escape virus. Nature Med. 3, 205-211 (1997).

28. Schmitz, J. E. et al. Control of viremia in simian immunodeficiency virus infection by $\mathrm{CD} 8^{+}$lymphocytes. Science 283, 857-860 (1999).

29. Jin, X. et al. Dramatic rise in plasma viremia after $C D 8(+)$ T-cell depletion in simian immunodeficiency virus-infected macaques. J. Exp. Med. 189, 991-998 (1999).

30. Baba, T. W. et al. Pathogenicity of live, attenuated SIV after mucosal infection of neonatal macaques. Science $\mathbf{2 6 7}$ 1820-1825 (1995)

31. Baba, T. W. et al. Live attenuated, multiply deleted simian immunodeficiency virus causes AIDS in infant and adult macaques. Nature Med. 5, 194-203 (1999).

32. Barouch, D. H. et al. Control of viremia and prevention of clinical AIDS in rhesus monkeys by cytokine-augmented DNA vaccination. Science 290, 486-492 (2000). The first report of the control of SHIV-89.6P challenge by a predominantly $\mathrm{T}$-cell response.

33. Amara, R. R. et al. Control of a mucosal challenge and prevention of AIDS by a multiprotein DNA/MVA vaccine. Science 292, 69-74 (2001).

\section{A demonstration of the ability of the memory} response that is raised by parenteral DNA or MVA immunizations to control a mucosal SHIV-89.6P challenge.

34. Shiver, J. W. et al. Replication-incompetent adenoviral vaccine vector elicits effective anti-immunodeficiency virus immunity. Nature 415, 331-335 (2002). A description of the ability of DNA-Ad5 and Ad5 to achieve control with only Gag expression.

35. Barouch, D. H. et al. Reduction of simian-human immunodeficiency virus $89.6 \mathrm{P}$ viremia in rhesus monkeys by recombinant modified vaccinia virus Ankara vaccination J. Virol. 75, 5151-5158 (2001).

36. Karlsson, G. B. et al. Characterization of molecularly cloned simian-human immunodeficiency viruses causing rapid $\mathrm{CD} 4{ }^{+}$Iymphocyte depletion in rhesus monkeys. J. Virol. $\mathbf{7 1}$ 4218-4225 (1997).

37. Mellors, J. W. et al. Prognosis in HIV-1 infection predicted by the quantity of virus in plasma. Science $\mathbf{2 7 2}, \mathbf{1 1 6 7 - 1 1 7 0}$ (1996).

38. Barouch, D. H. et al. Eventual AIDS vaccine failure in a rhesus monkey by viral escape from cytotoxic T lymphocytes. Nature 415, 335-339 (2002)

39. Quinn, T. C. et al. Viral load and heterosexual transmission of human immunodeficiency virus type 1. Rakai Project Study Group. N. Engl. J. Med. 342, 921-929 (2000)

40. Panicali, D. \& Paoletti, E. Construction of poxviruses as cloning vectors: insertion of the thymidine kinase gene from herpes simplex virus into the DNA of infectious vaccinia virus. Proc. Natl Acad. Sci. USA 79, 4927-4931 (1982).

41. Mackett, M., Smith, G. L. \& Moss, B. Vaccinia virus: a selectable eukaryotic cloning and expression vector. Proc Natl Acad Sci. USA 79, 7415-7419(1982).

42. Tang, D. C., De Vit, M. \& Johnston, S. A. Genetic immunization is a simple method for eliciting an immune response. Nature 356, 152-154 (1992).

43. Robinson, H. L., Hunt, L. A. \& Webster, R. G. Protection against a lethal influenza virus challenge by immunization with a haemagglutinin-expressing plasmid DNA. Vaccine 11, 957-960 (1993).

44. Ulmer, J. B. et al. Heterologous protection against influenza by injection of DNA encoding a viral protein. Science $\mathbf{2 5 9}$ 1745-1749 (1993).

45. MacGregor, R. R et al. First human trial of a DNA-based vaccine for treatment of human immunodeficiency virus type 1 infection: safety and host response. J. Infect. Dis. 178, 92-100 (1998).

46. Freed, E. O. \& Martin, M. A. in Fields Virology, Vol. 2 (eds Knipe, D. M. \& Howley, P. M.) 1971-2041 (Lippincott, Williams \& Wilkins, Philadelphia, 2001)

47. Lu, S., Santoro, J. C., Fuller, D. H., Haynes, J. R. \& Robinson, H. L. Use of DNAs expressing HIV-1 Env and noninfectious HIV-1 particles to raise antibody responses in mice. Virology 209, 147-154 (1995).

48. Zur Megede, J. et al. Increased expression and immunogenicity of sequence-modified human immunodeficiency virus type 1 gag gene. J. Virol. 74 2628-2635 (2000).
49. Huang, Y., Kong, W. P. \& Nabel, G. J. Human immunodeficiency virus type-1-specific immunity after genetic immunization is enhanced by modification of Gag and Pol expression. J. Virol. 75, 4947-4951 (2001).

50. Pontesilli, O. et al. Longitudinal analysis of human immunodeficiency virus type-1-specific cytotoxic T-lymphocyte responses: a predominant Gag-specific response is associated with nonprogressive infection. J. Infect. Dis. 178, 1008-1018 (1998).

51. Cohen, A. D., Boyer, J. D. \& Weiner, D. B. Modulating the immune response to genetic immunization. FASEB J. 12 1611-1626 (1998).

52. Singh, M., Briones, M., Ott, G. \& O'Hagan, D. Cationic microparticles: a potent delivery system for DNA vaccines. Proc. Natl Acad. Sci. USA 97, 811-816 (2000).

53. Widera, G. et al. Increased DNA vaccine delivery and immunogenicity by electroporation in vivo. J. Immunol. 164, 4635-4640 (2000)

54. Barouch, D. H. et al. Augmentation and suppression of immune responses to an HIV-1 DNA vaccine by plasmid cytokine/lg administration. J. Immunol. 161, 1875-1882 (1998).

55. Davis, N. L. et al. Vaccination of macaques against pathogenic simian immunodeficiency virus with Venezuelan equine encephalitis virus replicon particles. J. Virol. 74, 371-378 (2000)

56. Rose, N. F. et al. An effective AIDS vaccine based on live attenuated vesicular stomatitis virus recombinants. Cell 106 539-549 (2001).

57. Murphy, C. G. et al. Vaccine protection against simian immunodeficiency virus by recombinant strains of herpes simplex virus. J. Virol. 74, 7745-7754 (2000)

58. Liu, X. L., Clark, K. R. \& Johnson, P. R. Production of recombinant adeno-associated virus vectors using a packaging cell line and a hybrid recombinant adenovirus. Gene Ther. 6, 293-299 (1999).

59. Andino, R. et al. Enginerring poliovirus as a vaccine vector for the expression of diverse antigens. Science. $\mathbf{2 6 5}$ 1448-1451 (1994)

60. Shata, M. T., Reitz, M. S. Jr, DeVico, A. L., Lewis, G. K. \& Hone, D. M. Mucosal and systemic HIV-1 Env-specific CD8 ${ }^{+}$ T cells develop after intragastric vaccination with a Salmonella Env DNA vaccine vector. Vaccine 20, 623-629 (2001).

61. Mayr, A., Hochstein-Mintzel, V. \& Stickl, H. Abstammung, Eigenschaften und Verwendung des Attenuierten Vacciniastammes MVA. Infection 3, 6-14 (1975).

62. Mayr, A., Stickl, H., Muller, H. K., Danner, K. \& Singer, H. The small pox vaccination strain MVA: marker, genetic structure, experience gained with the parenteral vaccination and behavior in organisms with a debilitated defence mechanism. Zentralbl. Bakteriol. [B] 167, 375-390 (1978).

63. Antoine, G., Scheiflinger, F., Dorner, F. \& Falkner, F. G. The complete genomic sequence of the modified vaccin Ankara strain: comparison with other orthopoxviruses. Virology 244, 365-396 (1998).

64. Blanchard, T. J., Alcami, A., Andrea, P. \& Smith, G. L. Modified vaccinia virus Ankara undergoes limited replication in human cells and lacks severa immunomodulatory proteins: implications for use as a human vaccine. J. Gen. Virol. 79, 1159-1167 (1998).

65. Anderson, K. P. \& Fennie, E. H. Adenovirus early region $1 \mathrm{~A}$ modulation of interferon antiviral activity. J. Virol. 61 787-795 (1987).

66. Gutch, M. J. \& Reich, N. C. Repression of the interferon signal transduction pathway by the adenovirus $\mathrm{E} 1 \mathrm{~A}$ oncogene Proc Natl Acad Sci. USA 88, 7913-7917 (1991).

67. Reich, N., Pine, R., Levy, D. \& Darnell, J. E. Jr. Transcription of interferon-stimulated genes is induced by adenovirus particles but is suppressed by E1A gene products. J. Virol. 62, 114-119 (1988).

68. Andersson, M., McMichael, A. \& Peterson, P. A. Reduced allorecognition of adenovirus-2-infected cells. J. Immunol. 138, 3960-3966 (1987)

69. Burgert, H. G., Maryanski, J. L. \& Kvist, S. "E3/19K" protein of adenovirus type 2 inhibits lysis of cytolytic T lymphocytes by blocking cell-surface expression of histocompatibility clas I antigens. Proc. Natl Acad. Sci. USA 84, 1356-1360 (1987).

70. Gooding, L. R., Elmore, L. W., Tollefson, A. E., Brady, H. A. \& Gooding, L. R., Elmore, L. W., Tollefson, A. E., Brady, H. A.
Wold, W. S. A 14,700 MW protein from the E3 region of adenovirus inhibits cytolysis by tumor necrosis factor. Cell 53, 341-346 (1988).

71. Duerksen-Hughes, P. J., Hermiston, T. W., Wold, W. S. \& Gooding, L. R. The amino-terminal portion of CD1 of the adenovirus $\mathrm{E} 1 \mathrm{~A}$ proteins is required to induce susceptibility to tumor necrosis factor cytolysis in adenovirus-infected mouse cells. J. Virol. 65, 1236-1244 (1991).

72. Carroll, M. W. \& Moss, B. Host range and cytopathogenicity of the highly attenuated MVA strain of vaccinia virus: propagation and generation of recombinant viruses in a nonhuman mammalian cell line. Virology 238, 198-211 (1997).
73. Fallaux, F. J. et al. New helper cells and matched early region-1-deleted adenovirus vectors prevent generation of eplication-competent adenoviruses. Hum. Gene Ther. 9, 1909-1917 (1998).

74. Sutter, G. \& Moss, B. Nonreplicating vaccinia vector efficiently expresses recombinant genes. Proc. Natl Acad. Sci. USA 89, 10847-10851 (1992).

75. Chakrabarti, S., Sisler, J. R. \& Moss, B. Compact, synthetic, vaccinia virus early/late promoter for protein expression. Biotechniques 23, 1094-1097 (1997).

76. Zhong, L. et al. Presentation of SIVgag to monkey T cells using dendritic cells transfected with a recombinant adenovirus. Eur. J. Immunol. 30, 3281-3290 (2000).

77. Zhong, L., Granelli-Piperno, A., Choi, Y. \& Steinman, R. M. Recombinant adenovirus is an efficient and non-perturbing genetic vector for human dendritic cells. Eur. J. Immunol. $\mathbf{2 9}$ 964-972 (1999).

78. Ginsberg, H. S. et al. A mouse model for investigating the molecular pathogenesis of adenovirus pneumonia. Proc. Natl Acad. Sci. USA 88, 1651-1655 (1991).

79. Farina, S. F. et al. Replication-defective vector based on a chimpanzee adenovirus. J. Virol. 75, 11603-11613 (2001).

80. Henderson, D. A. \& Moss, B. Smallpox and Vaccinia W. B. Saunders, Philadelphia, 1999).

81. Schneider, J. et al. Induction of $C D 8^{+} T$ cells using heterologous prime-boost immunisation strategies. Immunol. Rev. 170, 29-38 (1999).

82. Ramshaw, I. A. \& Ramsay, A. J. The prime-boost strategy: exciting prospects for improved vaccination. Immunol. Today 21, 163-165 (2000).

83. Robinson, H. L., Smith, J. M., Amara, R. R. AIDS vaccines: heterologous prime/boost strategies for raising protective T-cell responses. AIDS Rev. 2, 105-110 (2000).

84. Li, S. et al. Priming with recombinant influenza virus followed by administration of recombinant vaccinia virus induces CD8 ${ }^{+}$T-cell-mediated protective immunity against malaria. Proc. Natl Acad. Sci. USA 90, 5214-5218 (1993).

85. Lu, S. et al. Simian immunodeficiency virus DNA vaccine trial in macaques. J. Virol. 70, 3978-3991 (1996).

86. Robinson, H. L. et al. Neutralizing antibody-independent containment of immunodeficiency virus challenges by DNA priming and recombinant pox virus booster immunization. Nature Med. 5, 526-534 (1999).

87. Boyer, J. D. et al. Protection of chimpanzees from high-dose heterologous HIV-1 challenge by DNA vaccination. Nature Med. 3, 526-532 (1997).

88. Haigwood, N. L. et al. Protection from pathogenic SIV challenge using multigenic DNA vaccines. Immunol. Lett. 66, 183-188 (1999).

89. Habel, A. et al. DNA vaccine protection against challenge with simian/human immunodeficiency virus 89.6 in rhesus macaques. Dev. Biol. (Basel) 104, 101-105 (2000).

90. Fynan, E. F. et al. DNA vaccines: protective immunizations by parenteral, mucosal and gene-gun inoculations. Proc Natl Acad Sci. USA 90, 11478-11482 (1993).

91. Feltquate, D. M., Heaney, S., Webster, R. G. \& Robinson, H. L. Different $T$ helper cell types and antibody isotypes generated by saline and gene gun DNA immunization. J. Immunol. 158, 2278-2284 (1997).

92. Hanke, T. et al. Effective induction of simian immunodeficiency virus-specific cytotoxic T lymphocytes in macaques by using a multiepitope gene and DNA primemodified vaccinia virus Ankara boost vaccination regimen. J. Virol. 73, 7524-7532 (1999).

93. Tanghe, A. et al. Tuberculosis DNA vaccine encoding Ag85A is immunogenic and protective when administered by intramuscular needle injection but not by epidermal gene gun bombardment. Infect. Immun. 68, 3854-3860 (2000).

94. Ourmanov, I. et al. Comparative efficacy of recombinant modified vaccinia virus Ankara expressing simian immunodeficiency virus (SIV) Gag-Pol and/or Env in macaques challenged with pathogenic SIV. J. Virol. 74, 2740-2751 (2000)

95. Pal, R. et al. ALVAC-SIV-gag-pol-env-based vaccination and macaque major histocompatibility complex class I $\left(\mathrm{A}^{\star} 01\right)$ delay simian immunodeficiency virus SIVmac-induced immunodeficiency. J. Virol. 76, 292-302 (2002).

96. Earl, P. L. et al. Comparison of vaccine strategies using recombinant env-gag-pol MVA with or without an oligomeric Env protein boost in the SHIV rhesus macaque model. Virology (in the press)

97. McMichael, A. J. et al. The dynamics of the cellular immune response to HIV infection: implications for vaccination. Phil. Trans. R. Soc. Lond. B 355, 1007-1011 (2000).

98. Feinberg, M. B. \& Moore, J. P. AIDS vaccine models: challenging challenge viruses. Nature Med. 8, 207-210 (2002).

99. Royce, R. A., Sena, A., Cates, W. J. \& Cohen, M. S. Current concepts: sexual transmission of HIV. N. Engl. J. Med. 336 1072-1078 (1997). 
100. Berman, P. W. et al. Genetic and immunologic characterization of viruses infecting MN-rgp120-vaccinated volunteers. J. Infect. Dis. 176, 384-397 (1997).

101. Cunningham, C. K. et al. Safety of two recombinant human immunodeficiency virus type 1 (HIV-1) envelope vaccines in neonates born to HIV-1-infected women. Clin. Infect. Dis. 32, 801-807 (2001)

102. Hanke, T. \& McMichael, A. J. Design and construction of an experimental HIV-1 vaccine for a year-2000 clinical trial in Kenya. Nature Med. 6, 951-955 (2000).

103. Moss, B. in Fields Virology, Vol. 2 (eds Knipe, D. M. \& Howley, P. M.) 2849-2883 (Lippincott, Williams and Wilkins, Philadelphia, 2001).

104. Ramirez, J. C., Gherardi, M. M. \& Esteban, M. Biology of attenuated modified vaccinia virus Ankara recombinant vecto in mice: vinus fate and activation of $B$ - and T-cellimmune responses in comparison with the Western Reserve strain and advantages as a vaccine. J. Virol. 74, 923-933 (2000).

105. Hel, Z. et al. Potentiation of simian immunodeficiency vir (SIV)-specific CD4 ${ }^{+}$and $\mathrm{CD} 8^{+} \mathrm{T}$-cell responses by a DNA (SIV)-specific CD4 ${ }^{+}$and CD8 ${ }^{+}$T-cell responses by a DNA-
SIV and NYVAC-SIV prime/boost regimen. J. Immunol. 167, 7180-7191 (2001).

106. Tartaglia, J. et al. Highly attenuated poxvirus vectors. AIDS . Tartaglia, J. et al. Highly attenuated poxvirus vecto
Res. Hum. Retroviruses 8, 1445-1447 (1992).

07. Plotkin, S. A. et al. The safety and use of canarypo vectored vaccines. Dev. Biol. Stand. 84, 165-170 (1995).

108. Paoletti, E. Applications of pox virus vectors to vaccination: an update. Proc. Natl Acad. Sci. USA 93, 11349-11353 (1996).

109. Belshe, R. B. et al. Induction of immune responses to HIVby canarypox virus (ALVAC) HIV-1 and gp120 SF-2 recombinant vaccines in uninfected volunteers. NIAID AIDS Vaccine Evaluation Group. AIDS 12, 2407-2415 (1998)

110. Shenk, T. E. in Fields Virology, Vol. 2 (eds Knipe, D. M. Howley, P. M.) 2265-2300 (Lippincott, Williams and Wilkins, Philadelphia, 2001)

111. Griffin, D. E. in Fields Virology, Vol. 2 (eds. Knipe, D. M. \& Howley, P. M.) 917-962 (Lippincott, Williams and Wilkins, Philadelphia, 2001

112. Rose, J. K. \& Whitt, M. A. in Fields Virology, Vol. 2 (eds Knipe, D. M. \& Howley, P. M.) 1221-1244 (Lippincott, Williams and Wilkins, Philadelphia, 2001).

113. Roizman, B. \& Knipe, D. M. in Fileds Virology, Vol. 2 (eds. Knipe, D. M. \& Howley, P. M.) 2399-2460 (Lippincott, Williams and Wilkins, Philadelphia, 2001).

114. Crotty, S. et al. Protection against simian immunodeficiency virus vaginal challenge by using Sabin poliovirus vectors. virus vaginal challenge by using
J. Virol. 75, 7435-7552 (2001).

115. Freed E. O. HIV-1 gag proteins: diverse functions in the virus life cycle. Virology 251, 1-15 (1998).

116. McCutchan, F. E in The Molecular Epidemiology of Infectious Diseases (ed. Thompson, R. C. A.) 143-167 (Hodder Arnold, London, 2000).

117. Amara, R. R. et al. Critical role for Env as well as Gag-Pol for the control of a pathogenic SHIV-89.6P challenge by a DNA/rMVA vaccine. J. Virol. (in the press).

Acknowledgements

I would like to thank B. Moss, H. Ertl, T. Mastro and R. Amara for critical comments. I am indebted to R. Amara for help with TABLE 2 and to J. Smith for help with FIG. 4, and I would like to thank
H. Drake-Perrow for expert administrative assistance. This work was supported in part by Integrated Preclinical/Clinical AIDS Vaccin Development Program projects, the Emory/Atlanta Center for AIDS (

\section{D) Online links}

\section{DATABASES}

The following terms in this article are linked online to:

Entrez: http://www.ncbi.nlm.nih.gov/entrez/query.fcgi?

$\mathrm{db}=$ Nucleotide

human adenovirus 5 | SHIV | vaccinia Ankara

LocusLink: http://wmwncbinlm nih gov/LocusLink/

L-1 | IL-2 | |L-6 | |L-12 | IFN- $\alpha / \beta$ | |FN- $\gamma$ | TNF

\section{FURTHER INFORMATION}

Encyclopedia of Life Sciences: http://www.els.net/ HIV | HIV life-cycle and inherited co-receptors

HIV Molecular Immunology Database: http://hiv-

web.lanl.gov/content/immunology/index html/index htm

HIV Vaccine Trials Network: http://wmwhwn of

IAVI Database of Preventitive AIDS Vaccines in Human Trials: http://www.lavi.org/trialsdb

ature's HIV Insite: http:/hivinsite.ucsf edu/InSite

UNAIDS: http://www.unaids.org/

Vaccine Research Center: http://www.vrc.nih.gov/NRC/ currenttrials.htm

Access to this interactive links box is free online. 